\title{
Metode Pengusangan Cepat dengan Larutan Etanol untuk Pengujian Vigor Daya Simpan Benih Caisin (Brassica rapa L. cv. grup Caisin)
}

\author{
Accelerated Aging Methods with Liquid Ethanol for Vigor Related to Storability \\ Testing of Caisin Seed (Brassica rapa L. cv. grup Caisin)
}

\author{
Aisa Amanah ${ }^{1}$, Maryati Sari ${ }^{2 *}$, dan Abdul Qadir ${ }^{2}$ \\ Diterima 9 Oktober 2015/Disetujui 26 Oktober 2016
}

\begin{abstract}
The objective of this study was to obtain effective duration in accelerated aging method with soaking the seed in $20 \%$ liquid ethanol which could estimate vigor related to storability of caisin seed during 3 and 6 months storage. There were five commercial caisin seed lots used in this study. The lots have different initial vigor. This research was conducted in two separate experiments. The first experiment was conducted to study deterioration of caisin seeds stored in aluminum foil pouches for 3 and 6 months at ambient room. The second experiment was conducted to study the effect of chemical aging duration, i.e 30, 60, 90, 120, 150, and 180 minutes moistened (12 hours imbibed) seed soaking in liquid ethanol 20\%. Both of experiments were arranged in completely nested design. Germination of seeds after soaking in 20\% liquid ethanol for 90 minutes was positively correlated with germination of seeds after storage for 3 and 6 months with coefficient of corellation $=0.87$ and 0.88. Both coefficient of corellations were close to 1 which showed that the germination of seeds after accelerated ageing with soaking in $20 \%$ liquid ethanol could estimate seed vigor related to storability. Vigor related to storability of caisin seed after 3 months could be predicted by the equation $y=56.04+0.36 x$ with the coefficient of determination 77.00\%. While after 6 months it can be predicted by the equation $y=62.72+0.38 x$ with the coefficient of determination $74.90 \%$. Y variable indicates germination of caisin seed after storage while the $x$ variable indicates germination of caisin seed after soaking in $20 \%$ liquid ethanol for 90 minutes.
\end{abstract}

Key words: deterioration, devigoration, longevity, seed storage, viability

\begin{abstract}
ABSTRAK
Penelitian ini dilakukan untuk mendapatkan waktu perendaman ke dalam etanol $20 \%$ yang tepat pada metode pengusangan cepat kimia yang dapat menduga vigor daya simpan benih caisin setelah penyimpanan 3 dan 6 bulan. Benih yang digunakan berasal dari lima lot benih komersial dengan vigor awal yang berbeda. Penelitian terdiri atas 2 percobaan terpisah. Percobaan 1 adalah penyimpanan benih caisin dalam kemasan aluminium foil selama 3 dan 6 bulan pada ruang suhu kamar. Percobaan 2 yaitu pengusangan cepat kimia dengan merendam benih caisin yang telah dilembabkan selama 12 jam ke dalam larutan etanol 20\% selama 30, 60, 90, 120, 150, dan 180 menit. Kedua percobaan menggunakan rancangan acak lengkap tersarang. Daya berkecambah benih setelah pengusangan melalui perendaman etanol $20 \%$ selama 90 menit berkorelasi positif dengan daya berkecambah benih setelah penyimpanan selama 3 dan 6 bulan. Nilai koefisien korelasi pada 3 dan 6 bulan setelah simpan adalah 0.87 dan 0.88 . Kedua koefisien korelasi tersebut mendekati 1 yang menunjukkan bahwa daya berkecambah benih setelah pengusangan cepat dengan etanol $20 \%$ dapat menduga vigor daya simpan. Vigor daya simpan benih caisin setelah 3 bulan simpan dapat diduga dengan persamaan $y=62.72+0.38 x$ dengan nilai koefisien determinasi sebesar $77.00 \%$, sementara setelah 6 bulan dapat diduga dengan persamaan $y=56.04+0.36 x$ dengan nilai koefisien determinasi sebesar $74.90 \%$. Peubah y menunjukkan daya berkecambah setelah penyimpanan

\footnotetext{
${ }^{1}$ Mahasiswa Program Sarjana Departemen Agronomi dan Hortikultura, Fakultas Pertanian, Institut Pertanian Bogor

${ }^{2}$ Staf Pengajar Departemen Agronomi dan Hortikultura, Fakultas Pertanian, Institut Pertanian Bogor (Bogor Agricultural University) Jl. Meranti, Kampus IPB Darmaga, Bogor 16680, Indonesia Telp.\& Faks. 62-251-8629353

Email: maryatisari@yahoo.com (*penulis korespondensi)
} 
sedangkan x menunjukkan daya berkecambah setelah pengusangan melalui perendaman etanol $20 \%$ selama 90 menit.

Kata kunci: daya simpan, deteriorasi, devigorasi, penyimpanan benih, viabilitas

\section{PENDAHULUAN}

Caisin (Brassica rapa L. cv. grup Caisin) merupakan salah satu komoditas hortikultura yang memiliki nilai komersial tinggi. Penggunaan benih yang bermutu dengan vigor tinggi merupakan salah satu upaya untuk meningkatkan produktivitas. Benih bermutu dengan vigor tinggi dapat diperoleh dari produsen yang telah melakukan proses sertifikasi benih. Salah satu informasi yang tercantum pada label kemasan benih bersertifikat adalah nilai daya berkecambah benih. Ketidaksesuaian nilai viabilitas benih dengan informasi yang tercantum pada label dapat terjadi apabila viabilitas benih menurun dengan cepat sehingga mendahului batas minimum daya berkecambah sebelum habis masa edarnya (masa kadaluarsa). Kondisi ini dapat terjadi bila pengujiam daya berkecambah dilakukan pada benih yang telah mendekati periode kritis dalam masa hidupnya atau memiliki vigor yang rendah akibat penanganan sebelum dan setelah panen, maupun selama penyimpanan yang tidak sesuai. Benih tersebut saat diuji mungkin memiliki daya berkecambah yang tinggi namun tidak dapat disimpan lebih lama lagi.

Vigor daya simpan $\left(\mathrm{V}_{\mathrm{DS}}\right)$ adalah suatu parameter vigor benih yang ditunjukkan dengan kemampuan benih untuk dapat disimpan dalam keadaan sub-optimum. Keadaan sub-optimum merupakan kondisi lingkungan (suhu dan kelembaban) tidak diatur atau kondisi ruang simpan terbuka. Vigor daya simpan dapat diuji menggunakan metode pengusangan cepat. Metode pengusangan cepat dapat berupa perlakuan fisik dengan pemberian suhu dan $\mathrm{RH}$ atau kadar air benih yang tinggi, maupun perlakuan kimia. Hasil Penelitian Rosida et al. (2015) hasil perlakuan pengusangan cepat melalui perendaman etanol pada 6 lot benih kubis dengan vigor awal yang berbeda menghasilkan korelasi yang erat dengan vigor daya simpan. Addai dan Kantankan (2006) melakukan perendaman benih kedelai dalam etanol $20 \%$ dan metanol $20 \%$ selama dua jam. Hasilnya menunjukkan bahwa perendaman dalam cairan etanol memberikan indikasi yang lebih baik terhadap perbedaan vigor daya simpan beberapa genotipe kedelai dibandingkan cairan metanol. Sementara itu, Ekowahyuni et al. (2012) mengemukakan bahwa pengusangan cepat menggunakan metanol $20 \%$ merupakan metode terbaik untuk menduga vigor daya simpan benih cabe, lebih baik dibanding penggunaan etanol 20\%. Larutan etanol maupun metanol keduanya dapat digunakan untuk mempercepat laju kemunduran benih. Ketika laju kemunduran dipercepat maka dengan mudah dapat dibedakan antara benih dengan vigor daya simpan yang tinggi dan yang rendah.

Penelitian ini bertujuan untuk mendapatkan waktu perendaman dan tolok ukur yang efektif pada metode pengusangan cepat secara kimia dengan perendaman ke dalam etanol $20 \%$ untuk menduga vigor daya simpan 5 lot benih caisin yang disimpan pada suhu kamar selama 3 dan 6 bulan.

\section{BAHAN DAN METODE}

Penelitian ini dilaksanakan di Laboratorium Ilmu dan Teknologi Benih, Departemen Agronomi dan Hortikultura, Fakultas Pertanian, Institut Pertanian Bogor. Penelitian dilaksanakan pada bulan Januari sampai Juli 2014. Bahan percobaan yang digunakan adalah lima lot benih caisin komersial yang diperoleh dari kios pertanian dengan akhir masa edar (tanggal kadaluarsa) masing-masing pada kemasan yaitu DRA (Januari 2016), GLR (Desember 2014), STJ (April 2014), KML (April 2014), dan TSK (April 2014) dan etanol.

Penelitian ini terdiri atas dua percobaan. Percobaan 1 menggunakan rancangan acak lengkap tersarang. Lot benih tersarang dalam periode simpan. Faktor pertama adalah lot benih caisin yang terdiri atas 5 taraf yaitu DRA, KML, TSK, GLR, dan STJ. Faktor kedua adalah periode simpan dengan tiga taraf yaitu 0,3 , dan 6 bulan. Percobaan dilakukan sebanyak 4 ulangan. Setiap satuan percobaan terdiri atas 
$2.5 \mathrm{~g}$ benih yang disimpan dalam kemasan aluminium foil. Penyimpanan dilakukan pada ruang simpan selama 0,3 , dan 6 bulan. Suhu ruang simpan berkisar $23.3-29.9{ }^{\circ} \mathrm{C}$ dan $\mathrm{RH}$ berkisar $61-85 \%$. Pengamatan dilakukan terhadap kadar air, daya berkecambah (DB), indeks vigor (IV) dan kecepatan tumbuh (Kct) benih setelah disimpan selama 0,3 , dan 6 bulan. Pengukuran kadar air simpan dilakukan dengan sampel sebanyak $2 \mathrm{~g}$ pada setiap ulangan. Metode pengujian kadar air dilakukan menggunakan oven suhu rendah $\left(105 \pm 2{ }^{\circ} \mathrm{C}\right)$ selama $17 \pm 1$ jam. Metode pengujian perkecambahan yang digunakan pada pengamatan adalah metode uji di atas kertas (UDK) dengan substrat kertas CD. Setiap satuan pengamatan terdiri atas 50 butir benih. Pengecambahan dilakukan dengan alat pengecambah benih (ecogerminator) tipe IPB 73-2A (suhu kamar 23.3-29.9 ${ }^{\circ} \mathrm{C}$ ), periode pengecambahan dilakukan selama 7 hari dengan pengamatan hitungan pertama pada 5 hari setelah tanam (hst) dan hitungan kedua pada 7 hst.

Percobaan 2 adalah pengusangan cepat berupa perendaman benih dalam etanol $20 \%$. Percobaan disusun dengan rancangan acak lengkap tersarang. Lot benih tersarang dalam waktu perendaman. Faktor pertama adalah lot benih caisin yang terdiri atas 5 taraf, yaitu DRA, KML, TSK, GLR, dan STJ. Benih yang digunakan berasal dari lot yang sama dengan benih pada Percobaan 1. Percobaan dilakukan bersamaan dengan dimulainya penyimpanan 0 bulan pada Percobaan 1. Faktor kedua adalah waktu perendaman dalam etanol $20 \%$ yang terdiri atas 6 taraf, yaitu 30, 60, 90, 120, 150, dan 180 menit. Percobaan dilakukan sebanyak 4 ulangan. Pengamatan setiap tolok ukur dalam tiap satuan percobaan terdiri atas 50 butir benih. Tahap awal dari pelaksanaan Percobaan 2 yaitu meningkatkan kadar air benih, setiap ulangan sebanyak $2 \mathrm{~g}$ benih. Peningkatan kadar air dilakukan dengan melembabkan benih pada kertas CD yang lembab selama 12 jam di dalam refrigerator suhu $5{ }^{0} \mathrm{C}$ sehingga kadar air meningkat menjadi $\pm 30 \%$ secara merata. Benih yang telah mengalami peningkatan kadar air secara merata selanjutnnya dikembalikan untuk menyesuaikan diri pada suhu ruang dan mengaktifkan proses metabolismenya. Benih kemudian direndam ke dalam $25 \mathrm{ml}$ etanol $20 \%$. Benih yang telah direndam kemudian ditiriskan lalu dikecambahkan menggunakan metode uji di atas kertas (UDK) di dalam alat pengecambah benih tipe IPB 73-2A. Pada setiap ulangan sebanyak 50 butir benih caisin dikecambahkan untuk pengamatan vigor daya simpan pada tolok ukur daya berkecambah $\left(\mathrm{V}_{\text {etanol(DB) }}\right)$, indeks vigor $\left(\mathrm{V}_{\text {etanol(IV) }}\right)$, dan kecepatan tumbuh $\left(\mathrm{V}_{\text {etanol(Kct) }}\right)$. Pengecambahan dilakukan selama 7 hari.

Data hasil kedua percobaan yang diperoleh diuji dengan analisis ragam. Uji lanjut dengan Duncan Multiple Range Test (DMRT) pada taraf $\alpha=5 \%$ dilakukan ketika analisis ragam menunjukkan pengaruh nyata. Hubungan antara kedua percobaan dianalisis menggunakan analisis korelasi dan regresi linier sederhana. Analisis korelasi digunakan untuk melihat keeratan antara daya berkecambah benih setelah penyimpanan pada Percobaan 1 dengan penduga vigor daya simpan yang diperoleh pada pengusangan cepat dengan perendaman dalam etanol 20\% pada tolok ukut daya berkecambah $\left(\mathrm{V}_{\text {etanol(DB) }}\right)$, indeks vigor $\left(\mathrm{V}_{\text {etanol(IV) }}\right)$, dan kecepatan tumbuh $\left(\mathrm{V}_{\text {etanol(Kct) }}\right)$. Analisis regresi linier sederhana dilakukan untuk mengetahui hubungan antara $\mathrm{V}_{\text {etanol(DB) }}, \quad \mathrm{V}_{\text {etanol(IV), }}$ dan $\mathrm{V}_{\text {etanol(Kct) }}$ pada perlakuan yang memberikan nilai korelasi yang erat terhadap daya berkecambah benih setelah disimpan. Berdasarkan analisis tersebut ditentukan model persamaan yang dapat menduga vigor daya simpan benih caisin.

Verifikasi model secara kualitatif diantaranya dengan menggunakan grafik yang dapat memvisualisasikan output model. Berdasarkan hasil verifikasi kualitatif, nilai dugaan dinyatakan berkesesuaian jika nilai hasil dugaan (simulasi) berada dalam selang standar deviasi dari hasil aktual. Verifikasi model secara kuantitatif menggunakan uji statistik, dilakukan dengan membandingkan secara berpasangan (uji-t) hasil simulasi dengan hasil aktual pada periode simpan yang sama. Berdasarkan verifikasi kuantitatif, hasil simulasi dinyatakan sesuai atau tidak berbeda dengan hasil aktual jika p-value lebih besar dari $\alpha(0.05)$.

\section{HASIL DAN PEMBAHASAN}

\section{Kondisi Umum}

Suhu ruang simpan selama percobaan berkisar 23.3-29.9 ${ }^{0} \mathrm{C}$ dan $\mathrm{RH}$ berkisar 61- 
85\%. Nilai daya berkecambah yang tertera pada kemasan benih yang digunakan berkisar $80-85 \%$ dan persentase kemurnian fisik $\geq 98 \%$. Persentase kadar air pada kemasan tidak tercantum. Berdasarkan pengujian selama penyimpanan kelima lot benih caisin memiliki kadar air berkisar 4.27-6.81\%. Nilai kadar air tersebut memenuhi syarat untuk perdagangan benih caisin yang ditetapkan oleh Dirbenhorti (2012), yaitu maksimum 8\%. Hal ini menunjukkan bahwa kemasan dan kondisi ruang simpan yang digunakan untuk penyimpanan benih caisin selama percobaan relatif aman. Sisa masa edar benih berdasarkan tanggal kadaluarsa dan pengujian 0 bulan pada percobaan ini adalah: DRA 24 bulan, GLR 11 bulan, STJ, KML, dan TSK 3 bulan (Tabel 1).

\section{Kemunduran Benih Selama Penyimpanan}

Percobaan 1 benih yang disimpan pasti mengalami kemunduran atau proses deteriorasi yang akan menyebabkan turunnya kualitas benih yaitu viabilitas dan vigor benih menjadi rendah. Laju kemunduran benih caisin selama periode simpan 0,3 , dan 6 bulan dapat ditunjukkan dengan nilai daya berkecambah, indeks vigor dan kecepatan tumbuh yang semakin berkurang seiring bertambah lamanya waktu penyimpanan.

Berdasarkan hasil pengamatan yang disajikan pada Tabel 1, secara umum kondisi pada awal penyimpanan kelima lot benih masih memenuhi syarat untuk diedarkan. Persyaratan teknis minimal untuk nilai DB benih caisin layak edar adalah $\geq 85 \%$ (Dirbenhorti, 2012). Laju deteriorasi pada setiap lot benih dapat berbeda meskipun pada awal penyimpanan memiliki nilai DB yang tidak berbeda nyata. Diantara lot DRA, KML, STJ, dan GLR yang di awal penyimpanan memiliki DB tidak berbeda nyata, ternyata setelah 6 bulan disimpan hanya lot DRA yang memiliki DB >85\%. Saat 3 bulan setelah simpan terdapat 2 lot dengan nilai DB $<85 \%$ (lot STJ $80.67 \%$ dan GLR 81.33\%). Lot GLR pada 3 bulan setelah simpan DB sudah turun hingga $81.33 \%$ dan pada 6 bulan setelah simpan hanya $72.00 \%$, padahal pada kemasan tercantum masa berlaku label hingga Desember 2014 (11 bulan sejak awal percobaan). Sangat dikhawatirkan bahwa pada 5 bulan berikutnya daya berkecambah akan menjadi terlalu rendah dan benih tidak layak untuk ditanam kembali. Laju penurunan nilai DB lot GLR yang lebih cepat dari batas kadaluarsanya menunjukkan bahwa nilai DB yang tercantum pada kemasan $(\geq 85 \%)$ hanya berlaku saat dilakukan pengujian saja, sehingga dapat terjadi ketidaksesuaian pada penetapan batas kadaluarsa benih. Kondisi tersebut memungkinkan benih masih beredar padahal nilai DB kurang dari standar layak edar. Hal ini dapat menyebabkan kerugian, baik bagi konsumen maupun produsen. Sementara itu, lot TSK mencantum masa berlaku label hingga April 2014 (3 bulan sejak awal percobaan), padahal hingga 6 bulan setelah simpan masih memiliki DB $86.67 \%$ (Tabel 1). Oleh karena itu, pendugaan vigor daya simpan benih sangat diperlukan dalam pengujian benih untuk menetapkan masa berlaku label.

Perbedaan laju deteriorasi dipengaruhi oleh berbagai faktor, baik faktor internal maupun eksternal. Faktor internal mencakup sifat genetik, vigor awal, kondisi kulit benih serta kadar air benih awal, sedangkan faktor eksternal mencakup kemasan, komposisi gas, suhu, dan kelembaban ruang simpan, serta mikroorganisme. Daya berkecambah yang tinggi di awal penyimpanan tidak selalu menjamin benih memiliki daya simpan lebih lama dibanding lot benih lainnya. Oleh karena itu, diperlukan pengembangan metoda yang dapat membedakan potensi daya simpan diantara lot benih (Shaban, 2013a).

Perbedaan laju penurunan daya berkecambah dapat disebabkan oleh pebedaan vigor awal yang dimiliki oleh masing-masing benih. Vigor benih dapat ditunjukkan oleh nilai indeks vigor (IV) dan kecepatan tumbuh $\left(\mathrm{K}_{\mathrm{CT}}\right)$. Tabel 1 menunjukkan bahwa sejak awal penyimpanan, lot GLR dan STJ memiliki nilai indeks vigor paling rendah dibanding ketiga lot lainnya.

Selama proses deteriorasi, penurunan vigor mendahului penurunan daya berkecambah benih itu sendiri (Shabah, 2013b), sehingga pengujian vigor dapat digunakan dalam pendugaan daya berkecambah benih setelah disimpan. Apabila perbedaan vigor tidak terdeteksi di awal penyimpanan, baik melalui pengamatan indeks vigor maupun kecepatan tumbuh, proses devigorasi (penguasangan cepat) dapat dilakukan, sebagaimana yang dilakukan pada Percobaan 2 dalam tulisan ini. 
Tabel 1. Daya berkecambah, indeks vigor, dan kecepatan tumbuh benih caisin setelah penyimpanan

\begin{tabular}{|c|c|c|c|c|}
\hline \multirow{2}{*}{$\begin{array}{c}\text { Lot } \\
\text { Benih }\end{array}$} & \multirow{2}{*}{$\begin{array}{c}\text { Sisa Masa } \\
\text { Kadaluarsa } \\
\text { (bulan) }\end{array}$} & \multicolumn{3}{|c|}{ Periode Simpan (bulan) } \\
\hline & & 0 & 3 & 6 \\
\hline & & \multicolumn{3}{|c|}{$\mathrm{DB}(\%)$} \\
\hline DRA & 24 & $90.7 \mathrm{Ab}$ & $92.7 \mathrm{Aa}$ & 86.0 Bab \\
\hline KML & 3 & $88.7 \mathrm{Ab}$ & $91.3 \mathrm{Aa}$ & $81.0 \mathrm{Bbc}$ \\
\hline TSK & 3 & $96.7 \mathrm{Aa}$ & $94.7 \mathrm{Ba}$ & 86.7 Ba \\
\hline STJ & 3 & 87.3 Ab & $80.7 \mathrm{Bb}$ & $76.0 \mathrm{Ccd}$ \\
\hline \multirow[t]{2}{*}{ GLR } & 11 & $86.0 \mathrm{Ab}$ & $81.3 \mathrm{Bb}$ & $72.0 \mathrm{Bd}$ \\
\hline & \multicolumn{4}{|c|}{ IV (\%) } \\
\hline DRA & 24 & $86.7 \mathrm{a}$ & $84.7 \mathrm{a}$ & $83.3 \mathrm{a}$ \\
\hline KML & 3 & $82.0 \mathrm{Ab}$ & $76.7 \mathrm{Bb}$ & 76.0 Babc \\
\hline TSK & 3 & $86.7 \mathrm{a}$ & $82.0 \mathrm{a}$ & $80.7 \mathrm{ab}$ \\
\hline STJ & 3 & $77.0 \mathrm{c}$ & $75.3 \mathrm{~b}$ & $73.3 \mathrm{bc}$ \\
\hline \multirow[t]{2}{*}{ GLR } & 11 & $76.0 \mathrm{Ac}$ & $75.3 \mathrm{Ab}$ & $68.7 \mathrm{Bc}$ \\
\hline & & \multicolumn{3}{|c|}{$\mathrm{K}_{\mathrm{CT}}\left(\% \mathrm{etmal}^{-1}\right)$} \\
\hline DRA & 24 & $25.7 \mathrm{Aa}$ & $24.6 \mathrm{Aa}$ & $22.2 \mathrm{Ba}$ \\
\hline KML & 3 & $23.6 \mathrm{Ab}$ & $21.7 \mathrm{Bb}$ & $19.7 \mathrm{Cb}$ \\
\hline TSK & 3 & $25.5 \mathrm{Aa}$ & $22.0 \mathrm{Bb}$ & $18.9 \mathrm{Cb}$ \\
\hline STJ & 3 & $23.5 \mathrm{Ab}$ & $20.0 \mathrm{Bc}$ & $18.4 \mathrm{Bb}$ \\
\hline GLR & 11 & $23.3 \mathrm{Ab}$ & $19.8 \mathrm{Bc}$ & $16.3 \mathrm{Cc}$ \\
\hline
\end{tabular}

Keteragnan: Angka-angka sebaris yang diikuti huruf besar yang sama dan angka-angka sekolom yang diikuti huruf kecil yang sama tidak berbeda nyata pada taraf nyata uji 5\% (uji selang berganda Duncan); KK: koefisien keragaman hasil uji-F; periode 0, bulan Januari 2014; periode 3, bulan April 2014; periode 6, bulan Juli 2014.

\section{Devigorasi dengan Perendaman Benih Caisin ke Dalam Larutan Etanol 20\%}

Percobaan 2 devigorasi adalah laju kemunduran benih akibat perlakuan buatan seperti pengusangan cepat. Devigorasi pada percobaan ini dilakukan dengan pengusangan secara kimia melalui perendaman benih ke dalam etanol $20 \%$. Laju kemunduran secara buatan (devigorasi) dapat dilihat dengan mengamati nilai vigor setelah pengusangan dengan pengamatan daya berkecambah benih setelah diusangkan $\left(\mathrm{V}_{\text {etanol(DB) }}\right)$, indeks vigor benih setelah dingusangkan $\left(\mathrm{V}_{\text {etanol(IV) }}\right)$, dan kecepatan tumbuh benih setelah diusangkan $\left(\mathrm{V}_{\text {etanol(Kct) }}\right)$. Hasil penelitian Salehi et al. (2008) menunjukkan bahwa pada benih rumput yang direndam dalam etanol $10 \%$ selama 4 jam dapat mengalami laju kemunduran yang sangat berbeda meskipun viabilitas awalnya tidak terlalu berbeda. Rumput marga Lolium yang direndam dalam etanol $10 \%$ mengalami penurunan daya berkecambah dari $89.5 \%$ (0 jam perendaman) menjadi $5.75 \%$ (4 jam perendaman), sedangkan marga Festuca dari $87 \%$ (0 jam perendaman) menjadi $6 \%$ (4 jam perendaman).
Kelima lot yang diuji, masih memenuhi persyaratan daya berkecambah $\geq 85 \%$. Empat lot diantaranya tidak berbeda nyata, hanya lot TSK yang nyata memiliki DB lebih tinggi dibanding lot lainnya (Tabel 1). Viabilitas semakin turun seiring dengan bertambahnya waktu perendaman. Semakin lama waktu perendaman benih caisin ke dalam etanol $20 \%$ maka vigor benih caisin semakin menurun yang ditunjukkan pada tolok ukur $\mathrm{V}_{\text {etanol(DB) }}$ ), $\left(\mathrm{V}_{\text {etanol(IV) }}\right)$, maupun $\left(\mathrm{V}_{\text {etanol(Kct) }}\right)$ (Tabel 2). Deteriorasi benih caisin mengalami penurunan dipercepat pada semua tolok ukur, diduga karena benih yang telah direndam ke dalam etanol mengalami kerusakan pada protein yang merupakan komponen penting pada benih.

Apabila benih direndam dalam larutan etanol maka etanol dapat berpenetrasi ke dalam komponen lipida dari membran setelah membran sel rusak, memutuskan ikatan lipida, bahkan dapat membuang fosfolipida dari membran. Ketika etanol masuk ke dalam benih, etanol dapat menyebabkan teracaknya konfigurasi protein yang berasosiasi dengan membran (Priestley dan Leopold, 1980). 
J. Hort. Indonesia 7(3): 165-175. Desember 2016.

Tabel 2. Kemunduran mutu benih caisin setelah pengusangan dengan perendaman ke dalam etanol $20 \%$

\begin{tabular}{|c|c|c|c|c|c|c|}
\hline \multirow{2}{*}{ Lot Benih } & \multicolumn{6}{|c|}{ Waktu Perendaman (menit) } \\
\hline & 30 & 60 & 90 & 120 & 150 & $180^{\mathrm{b}}$ \\
\hline & \multicolumn{6}{|c|}{$\mathrm{V}_{\text {etanol (DB) }}(\%)$} \\
\hline DRA & $92.0 \mathrm{a}$ & $86.0 \mathrm{a}$ & $84.7 \mathrm{a}$ & $82.7 \mathrm{a}$ & $81.3 \mathrm{a}$ & $56.8 \mathrm{a}$ \\
\hline KML & $92.0 \mathrm{a}$ & $81.3 \mathrm{ab}$ & $74.7 \mathrm{c}$ & $60.7 \mathrm{c}$ & $52.0 \mathrm{~b}$ & $41.6 \mathrm{~b}$ \\
\hline TSK & $84.0 \mathrm{~b}$ & $78.7 \mathrm{~b}$ & $78.7 \mathrm{~b}$ & $68.0 \mathrm{~b}$ & $45.3 \mathrm{c}$ & $40.4 \mathrm{~b}$ \\
\hline STJ & $83.3 \mathrm{~b}$ & $63.3 \mathrm{c}$ & $50.0 \mathrm{~d}$ & $46.7 \mathrm{~d}$ & $30.7 \mathrm{e}$ & $29.8 \mathrm{~d}$ \\
\hline \multirow[t]{2}{*}{ GLR } & $70.0 \mathrm{c}$ & $55.3 \mathrm{~d}$ & $50.0 \mathrm{~d}$ & $48.7 \mathrm{~d}$ & $40.7 \mathrm{~d}$ & $36.1 \mathrm{c}$ \\
\hline & \multicolumn{6}{|c|}{.. $\mathrm{V}_{\text {etanol (IV) }}(\%)$} \\
\hline DRA & $86.0 \mathrm{a}$ & $85.3 \mathrm{a}$ & $82.7 \mathrm{a}$ & $75.3 \mathrm{a}$ & $62.7 \mathrm{a}$ & $52.0 \mathrm{a}$ \\
\hline KML & $88.7 \mathrm{a}$ & $73.3 \mathrm{~b}$ & $72.7 \mathrm{~b}$ & $60.0 \mathrm{~b}$ & $44.0 \mathrm{~b}$ & $29.9 \mathrm{~b}$ \\
\hline TSK & $78.0 \mathrm{~b}$ & $72.7 \mathrm{~b}$ & $68.7 \mathrm{~b}$ & $63.3 \mathrm{~b}$ & $40.0 \mathrm{c}$ & $32.4 \mathrm{~b}$ \\
\hline STJ & $78.0 \mathrm{~b}$ & $53.3 \mathrm{c}$ & $46.7 \mathrm{c}$ & $35.3 \mathrm{c}$ & $24.7 \mathrm{~d}$ & $24.6 \mathrm{c}$ \\
\hline \multirow[t]{2}{*}{ GLR } & $66.7 \mathrm{c}$ & $46.7 \mathrm{~d}$ & $46.0 \mathrm{c}$ & $41.3 \mathrm{c}$ & $37.3 \mathrm{c}$ & $34.0 \mathrm{~b}$ \\
\hline & \multicolumn{6}{|c|}{$\mathrm{V}_{\text {etanol (KCT) }}\left(\%\right.$ etmal $\left.^{-1}\right)$} \\
\hline DRA & $21.8 \mathrm{~b}$ & $21.0 \mathrm{a}$ & $20.6 \mathrm{a}$ & $19.4 \mathrm{a}$ & $17.4 \mathrm{a}$ & $15.2 \mathrm{a}$ \\
\hline KML & $22.3 \mathrm{a}$ & $19.0 \mathrm{~b}$ & $17.6 \mathrm{~b}$ & $13.8 \mathrm{c}$ & $11.6 \mathrm{~b}$ & $9.3 \mathrm{~b}$ \\
\hline TSK & $19.4 \mathrm{c}$ & $18.5 \mathrm{~b}$ & $17.8 \mathrm{~b}$ & $16.0 \mathrm{~b}$ & $10.9 \mathrm{~b}$ & $8.6 \mathrm{~b}$ \\
\hline STJ & $19.7 \mathrm{c}$ & $14.1 \mathrm{c}$ & $11.7 \mathrm{c}$ & $10.0 \mathrm{~d}$ & $6.8 \mathrm{~d}$ & $5.0 \mathrm{c}$ \\
\hline GLR & $16.5 \mathrm{~d}$ & $12.3 \mathrm{~d}$ & $11.6 \mathrm{c}$ & $10.9 \mathrm{~d}$ & $9.6 \mathrm{c}$ & $8.1 \mathrm{~b}$ \\
\hline
\end{tabular}

Keterangan: Angka pada kolom yang sama, diikuti oleh huruf yang sama tidak berbeda nyata pada taraf uji 5\% (uji selang berganda Duncan); ${ }^{b}$ Hasil transformasi arcsin pada tolok ukur $\mathrm{V}_{\text {etanol (IV) }}$ selama perendaman 180 menit; KK: koefisien keragaman hasil uji-F.

Pada penyimpanan benih secara alami, hilangnya integritas membran juga merupakan salah satu penyebab utama hilangnya viabilitas. Pada kondisi penyimpanan yang tidak kondusif, hilangnya permeabilitas membran meningkatkan kebocoran elektrolit yang berakibat hilangnya viabilitas. Penurunan daya berkecambah, daya tumbuh di lapangan dan vigor benih berasosiasi dengan semakin tingginya kebocoran elektrolit benih (Jyoti dan Malik, 2013). Etanol merupakan salah satu senyawa volatil yang diproduksi benih selama deteriorasi (Shaban, 2013b). Woodstock dan Taylorson (1981) mengemukakan pula bahwa etanol mengalami peningkatan selama proses imbibisi, dan menjadi penyebab hilangnya integritas membran, peningkatan etanol pada benih bervigor tinggi lebih lambat dibanding peningkatannya pada benih bervigor rendah.

\section{Hubungan Daya Berkecambah Benih Setelah Disimpan dengan Devigorasi dalam Etanol 20\%}

Daya berkecambah benih setelah disimpan menunjukkan adanya variasi lebih tinggi dibandingkan daya berkecambah diawal penyimpanan (Tabel 1), demikian pula laju kemunduran benih akibat pengusangan dengan perendaman dalam etanol (Tabel 2).

Uji korelasi dilakukan untuk melihat hubungan antara $\left(\mathrm{V}_{\text {etanol(DB) }}\right),\left(\mathrm{V}_{\text {etanol(IV) }}\right)$, dan $\left(\mathrm{V}_{\text {etanol(Kct) }}\right)$ setelah benih didera dalam etanol $20 \%$ dengan daya berkecambah benih setelah disimpan (Tabel 3). Hasil analisis korelasi pada Tabel 3 menunjukkan adanya korelasi positif antara vigor benih setelah pengusangan cepat dengan etanol $20 \%$ pada tolok ukur

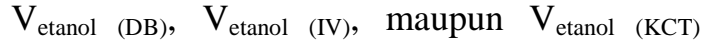
dengan daya berkecambah benih setelah disimpan selama 3 dan 6 bulan. Semua waktu deraan menunjukkan korelasi yang nyata kecuali pada waktu deraan 180 menit pada

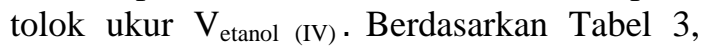
nilai koefisien korelasi tertinggi terdapat pada waktu perendaman 90 menit pada tolok ukur $\mathrm{V}_{\text {etanol(DB) }}$ dengan koefisien korelasi sebesar 0.88 setelah penyimpanan 3 bulan dan 0.87 setelah penyimpanan 6 bulan. Tolok ukur $\mathrm{V}_{\text {etanol(DB) }}$ pada perendaman selama 90 menit dipilih karena memiliki korelasi erat, koefisien korelasi mendekati 1 secara konsisten baik terhadap daya berkecambah 3 maupun 6 bulan setelah penyimpanan. Koefisien korelasi yang 
positif menunjukkan bahwa semakin kecil nilai $\mathrm{V}_{\text {etanol (DB) }}$ maka semakin kecil pula nilai daya berkecambah benih setelah disimpan. Setelah analisis korelasi menunjukkan hubungan yang erat maka dilakukan analisis regresi linier sederhana.

\section{Pendugaan Vigor Daya Simpan Benih Caisin}

Analisis regresi linier sederhana yang menghubungkan antara daya berkecambah setelah disimpan dengan tolok ukur vigor setelah benih diusangkan selama 90 menit dalam etanol 20\% disajikan pada Tabel 4. Vigor daya simpan benih caisin selama 3 bulan dapat diduga dengan persamaanya $=$ $62.72+0.38 \mathrm{x}$, dengan $\mathrm{x}$ adalah $\mathrm{V}_{\text {etanol(DB) }}$ pada pengusangan selama 90 menit dan y adalah daya berkecambah setelah disimpan 3 bulan. Nilai koefisien korelasi sebesar 0.88 dan nilai koefisien determinasi sebesar $77.00 \%$. Nilai koefisien determinasi sebesar $77.00 \%$ menunjukkan bahwa sebesar $77.00 \%$ keragaman daya berkecambah setelah disimpan 3 bulan dapat diterangkan oleh $\mathrm{V}_{\text {etanol(DB) }}$ pada pengusangan selama 90 menit, sedangkan $23.00 \%$ sisanya diterangkan oleh faktor lain di luar percobaan. Sementara itu, vigor daya simpan benih caisin yang telah disimpan selama 6 bulan dapat diduga melaluipersamaan $\mathrm{y}=56.04+0.36 \mathrm{x}$, dengan $\mathrm{x}$ adalah $\mathrm{V}_{\text {etanol (DB) }}$ pada pengusangan selama 90 menit dan y adalah DB setelah disimpan 6 bulan. Nilai koefisien korelasi sebesar 0.87 dan nilai koefisien determinasi sebesar $74.90 \%$. Nilai koefisien determinasi sebesar $74.90 \%$ menunjukkan bahwa sebesar $74.90 \%$ keragaman DB setelah disimpan 6 bulan dapat diterangkan oleh $\mathrm{V}_{\text {etanol(DB) }}$ pada pengusangan selama 90 menit, sedangkan $25.10 \%$ sisanya diterangkan oleh faktor lain diluar percobaan.

Tabel 3. Rekapitulasi hasil analisis korelasi antara vigor daya simpan setelah deteriorasi dengan devigorasi

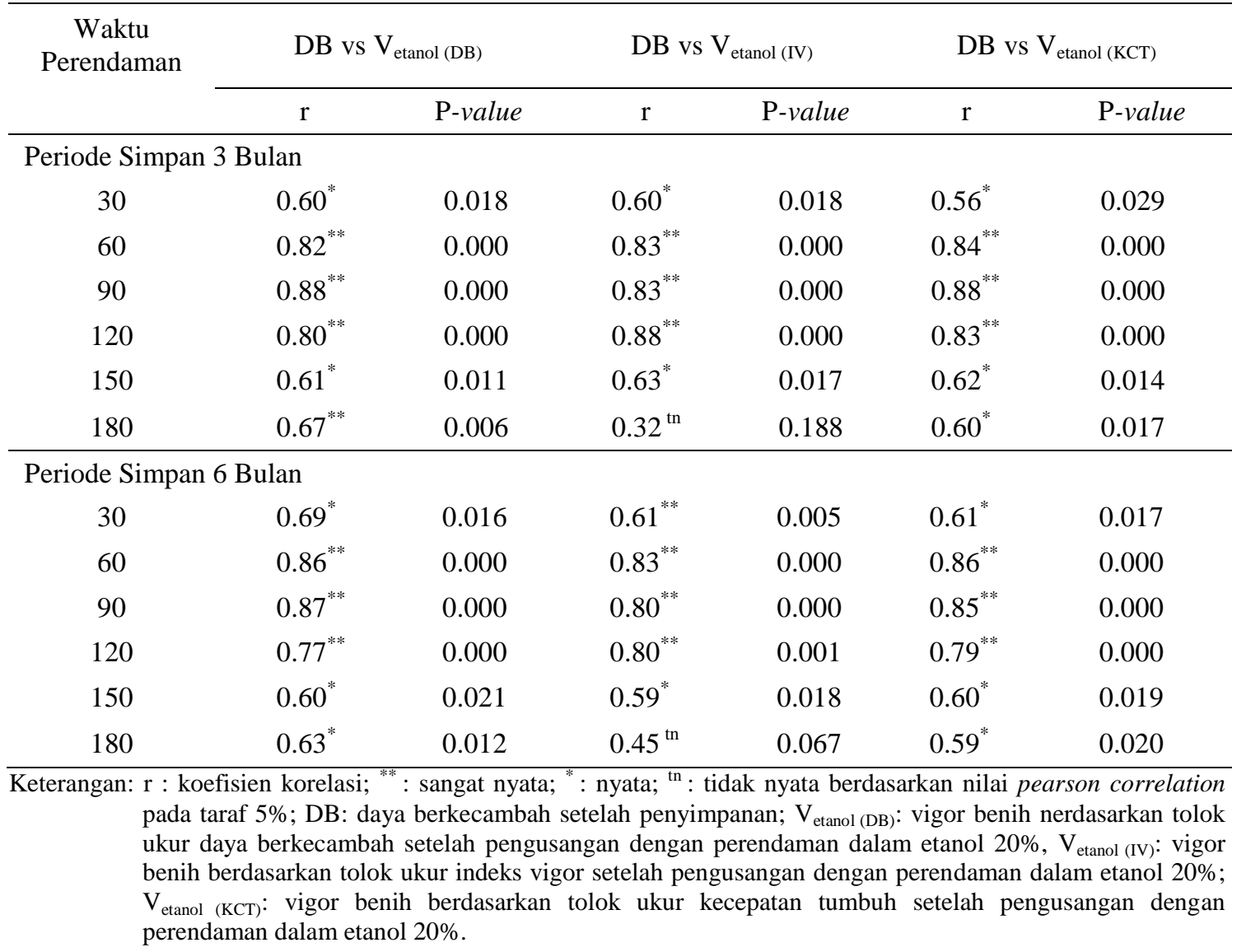




\section{Verifikasi Model Persamaan Pendugaan Vigor Daya Simpan}

Verifikasi model dimaksudkan sebagai tahapan kegiatan pemodelan yang bertujuan untuk menilai kesesuaian hasil simulasi dengan hasil aktual (Qadir, 2012). Hasil aktual diperoleh dari hasil pengujian Percobaan 1 yaitu deteriorasi selama penyimpanan pada tolok ukur daya berkecambah selama 3 dan 6 bulan simpan. Hasil simulasi diperoleh dengan mensubstitusikan hasil pengujian pada Percobaan 2 yaitu nilai $\mathrm{V}_{\text {etanol }}$ (DB) pada pengusangan selama 90 menit (peubah $\mathrm{x}$ ) ke dalam model persamaan hasil analisis regresi (Tabel 4) sehingga diperoleh nilai daya berkecambah setelah penyimpanan selama 3 dan 6 bulan (peubah y) untuk dijadikan sebagai DB (3 bulan) simulasi dan DB (6 bulan) simulasi.

Berdasarkan Tabel 5 verifikasi data secara kuantitatif menunjukkan model tidak dapat menduga secara tepat DB (3 bulan) pada lot benih DRA karena data hasil simulasi keluar dari selang standar deviasi. Namun demikian, secara umum hasil verifikasi DB aktual dan DB simulasi menggunakan uji-t pada Tabel 5 menunjukkan nilai p-value sebesar 0.93 pada penyimpanan 3 bulan dan 0.76 pada penyimpanan 6 bulan. Nilai p-value lebih besar dari $\alpha(0.05)$ pada uji-t, berarti hasil simulasi tidak berbeda nyata dengan hasil aktual. Kesesuaian antara DB aktual dengan DB simulasi pada verifikasi secara kuantitatif menunjukkan bahwa model persamaan pendugaan vigor daya simpan pada Tabel 4 dapat digunakan untuk menduga vigor daya simpan benih caisin setelah penyimpanan selama 3 bulan maupun 6 bulan.

Verifikasi secara kualitatif (Gambar 1) mendukung adanya kesesuaian antara DB (3 bulan) hasil aktual dengan DB (3 bulan) hasil simulasi untuk lot benih GLR, STJ, KML, dan TSK yang didasarkan pada data hasil simulasi yang berada dalam selang standar deviasi dari hasil aktual. Sementara itu, Gambar 2 mendukung adanya kesesuaian antara DB (6 bulan) hasil aktual dengan DB (6 bulan) hasil simulasi untuk semua lot benih yang diuji.

Tabel 4. Rekapitulasi hasil analisis regresi antara tolok ukur $\mathrm{V}_{\text {etanol(DB) }}$ pada pengusangan selama 90 menit dengan tolok ukur DB setelah penyimpanan 3 dan 6 bulan

\begin{tabular}{lccc}
\hline \multicolumn{1}{c}{ Periode Simpan } & Model & $\mathrm{R}^{2}$ & $\mathrm{r}$ \\
\hline 3 Bulan & $\mathrm{y}=62.72+0.38 \mathrm{x}$ & $77.00 \%$ & 0.88 \\
6 Bulan & $\mathrm{y}=56.04+0.36 \mathrm{x}$ & $74.90 \%$ & 0.87 \\
\hline
\end{tabular}

Keterangan: y : daya berkecambah setelah penyimpanan 3 bulan atau 6 bulan; $x: V_{\text {etanol (DB) }}$ pada pengusangan selama 90 menit (vigor benih pada tolok ukur daya berkecambah setelah perendaman dalam etanol $20 \%$; $\mathrm{R}^{2}$ : koefisien determinasi; r: koefisien korelasi.

Tabel 5. Hasil uji-t antara daya berkecambah aktual (DB aktual) dengan daya berkecambah simulasi (DB simulasi) setelah 3 dan 6 bulan simpan

\begin{tabular}{lccccccc}
\hline $\begin{array}{l}\text { Lot } \\
\text { Benih }\end{array}$ & $\begin{array}{c}\mathrm{V}_{\text {etanol (DB) }} \\
(\%)\end{array}$ & $\begin{array}{c}\text { DB Aktual } \\
\text { 3 Bulan } \\
(\%)\end{array}$ & $\begin{array}{c}\text { DB Simulasi } \\
\text { 3 Bulan } \\
(\%)\end{array}$ & Sd & $\begin{array}{c}\text { DB Aktual } \\
\text { 6 Bulan } \\
(\%)\end{array}$ & $\begin{array}{c}\text { DB Simulasi } \\
\text { 6 Bulan } \\
(\%)\end{array}$ & Sd \\
\hline DRA & 84.67 & 92.67 & 94.89 & 1.15 & 86.00 & 86.52 & 2.00 \\
KML & 74.67 & 91.33 & 91.09 & 4.16 & 87.00 & 82.92 & 3.00 \\
TSK & 78.67 & 94.67 & 92.61 & 3.06 & 86.67 & 84.36 & 4.62 \\
STJ & 50.00 & 80.67 & 81.72 & 1.15 & 76.00 & 74.04 & 2.00 \\
GLR & 50.00 & 81.33 & 81.72 & 3.06 & 72.00 & 74.04 & 2.00 \\
\hline
\end{tabular}

Uji-t

$\mathrm{P}$-value $=0.95^{\mathrm{tn}}$

$\mathrm{P}$-value $=0.76^{\mathrm{tn}}$

Keterangan: DB aktual adalah daya berkecambah benih setelah disimpan dalam kemasan aluminium foil pada suhu 23.3-29.9 ${ }^{\circ} \mathrm{C}$ dan RH 61-85\%; DB simulasi: daya berkecambah benih dugaan berdasarkan persamaan regresi hubungan daya berkecambah benih setelah disimpan dengan daya berkecambah benih setelah pengusangan dengan perendaman dalam etanol 20\% selama 90 menit; $\mathrm{V}_{\text {etanol (DB) }}(\%)$ : daya berkecambah setelah pengusangan dengan perendaman dalam etanol $20 \%$ selama 90 menit; Sd: standar deviasi. 


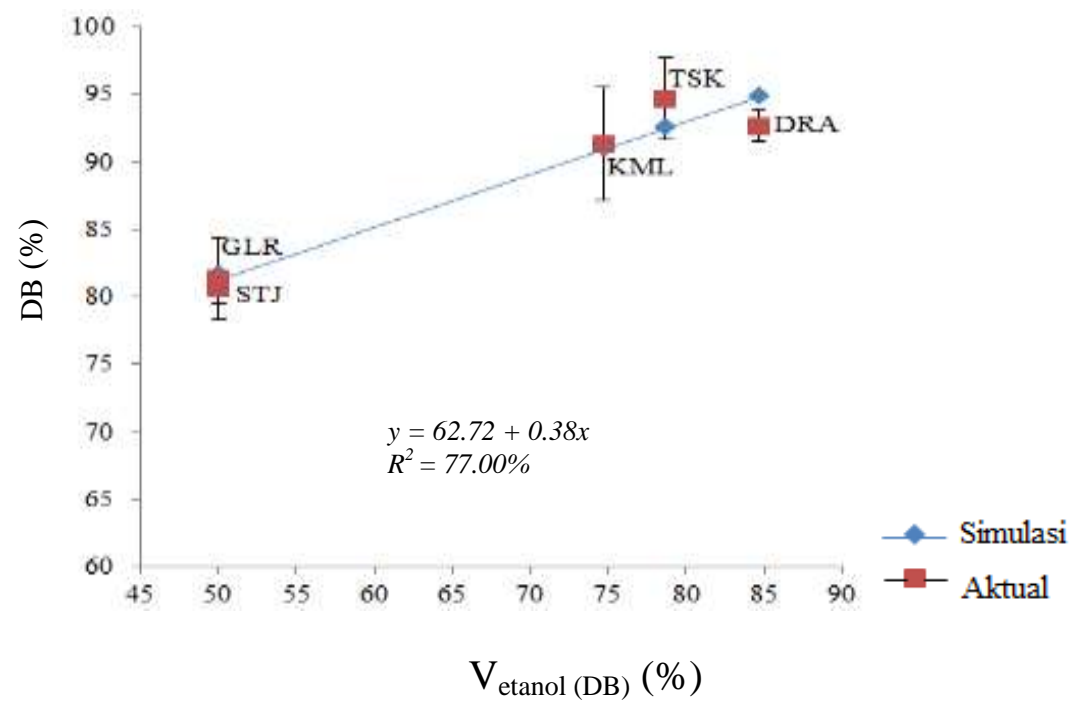

Gambar 1. Vigor daya simpan benih caisin pada periode simpan 3 bulan hasil simulasi dan aktual. Garis vertikal di atas tiap titik data menunjukkan nilai standar deviasi dari data aktual, DB menunjukkan daya berkecambah setelah penyimpanan selama 3 bulan, dan $\mathrm{V}_{\text {etanol(DB) }}$ menunjukkan penduga vigor daya simpan pada tolok ukur daya berkecambah setelah pengusangan dengan perendaman ke dalam etanol $20 \%$ selama 90 menit.

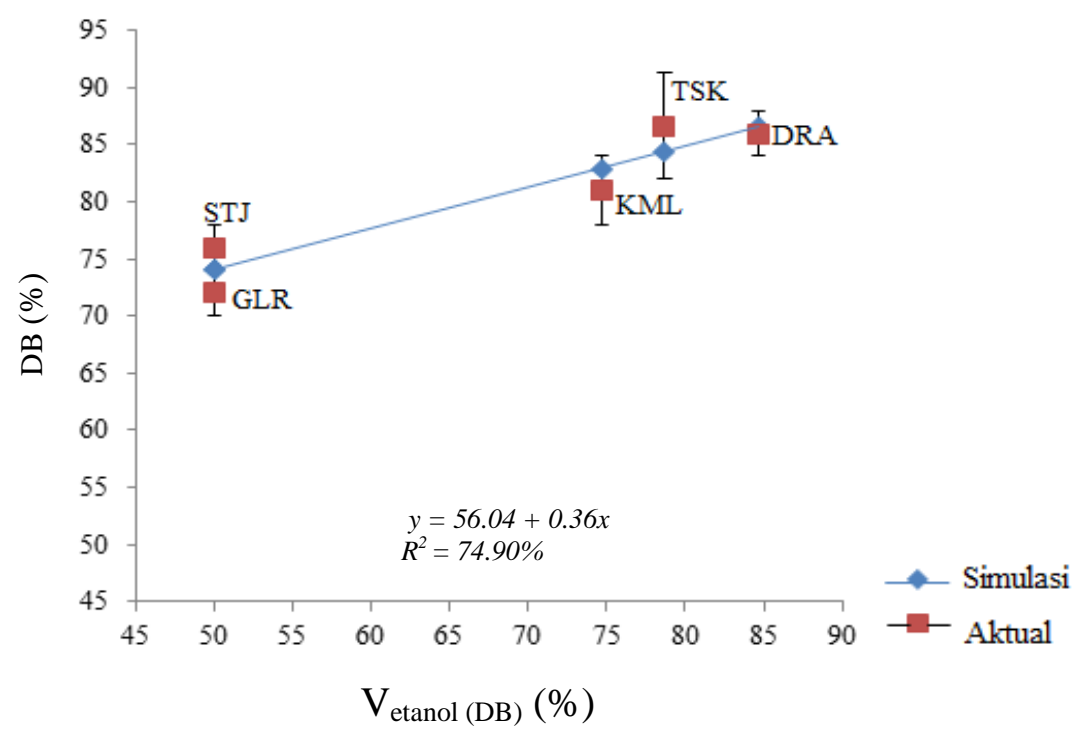

Gambar 2. Vigor daya simpan benih caisin pada periode simpan 6 bulan hasil simulasi dan aktual. Garis vertikal di atas tiap titik data menunjukkan nilai standar deviasi dari data aktual DB menunjukkan daya berkecambah setelah penyimpanan selama 6 bulan, dan $\mathrm{V}_{\text {etanol(DB) }}$ menunjukkan penduga vigor daya simpan pada tolok ukur daya berkecambah setelah pengusangan dengan perendaman etanol $20 \%$ selama 90 menit.

Pendugaan vigor daya simpan benih setelah penyimpanan selama 3 dan 6 bulan ditetapkan mengacu pada nilai DB minimum benih caisin layak edar yaitu $85 \%$. Nilai DB $85 \%$ disubstitusikan ke dalam peubah y pada model persamaan Tabel 4 sehingga diperoleh nilai $\mathrm{V}_{\text {etanol(DB) }}$ minimum yang dapat dijadikan sebagai pendugaan lot benih caisin masih layak edar ( $\mathrm{DB} \geq 85 \%)$ dalam jangka waktu 3 dan 6 bulan setelah pengujian (Tabel 6). 
Tabel 6. Nilai minimum $\mathrm{V}_{\text {etanol(DB) }}(\%)$ untuk mendapatkan DB $\geq 85 \%$ setelah penyimpanan benih caisin selama 3 dan 6 bulan.

\begin{tabular}{|c|c|c|}
\hline \multirow{2}{*}{ Tolok ukur } & \multicolumn{2}{|c|}{ Periode Simpan (bulan) } \\
\hline & 3 & 6 \\
\hline $\mathrm{V}_{\text {etanol(DB) }}(\%)$ & 58.63 & 80.44 \\
\hline $\mathrm{R}^{2}(\%)$ & 77.00 & 74.90 \\
\hline $\mathrm{Sd}$ & 3.72 & 3.58 \\
\hline $\begin{aligned} \text { Keterangan: } & \mathrm{V}_{\text {eta }} \\
& \text { pen } \\
& 20 \% \\
& \text { dete }\end{aligned}$ & $\begin{array}{l}\text { daya ber } \\
\text { n melalui } \\
\text { a } 90 \text { mer } \\
\text {; Sd: stand }\end{array}$ & $\begin{array}{l}\text { ah setelah } \\
\text { man etanol } \\
: \text { koefisien } \\
\text { asi }\end{array}$ \\
\hline
\end{tabular}

Berdasarkan Tabel 6, benih caisin masih layak edar apabila setelah pengujian vigor dengan perendaman dalam etanol $20 \%$ selama 90 menit, memiliki nilai $\mathrm{V}_{\text {etanol(DB) }} \geq(58.63 \pm$ $3.72) \%$ untuk 3 bulan setelah pengujian, dan $\geq(80.44 \pm 3.58) \%$ untuk masa edar hingga 6 bulan setelah pengujian.

\section{KESIMPULAN}

Metode pengusangan cepat kimia dengan perendaman benih ke dalam larutan etanol 20\% merupakan metode yang dapat digunakan dalam pendugaan vigor daya simpan benih caisin. Vigor daya simpan benih setelah 3 dan 6 bulan simpan dapat diduga berdasarkan tolok ukur $\mathrm{V}_{\text {etanol(DB), dengan }}$ waktu perendaman efektif ke dalam etanol $20 \%$ yaitu 90 menit. Model persamaan yang dapat digunakan sebagai pendugaan vigor daya simpan benih caisin setelah 3 bulan simpan adalah $\mathrm{y}=62.72+0.38 \mathrm{x}$. Nilai koefisien korelasi adalah 0.87 dan nilai koefisien determinasi sebesar $77.00 \%$. Model persamaan yang dapat digunakan sebagai pendugaan vigor daya simpan benih caisin setelah 6 bulan simpan adalah y $=56.04+0.36 \mathrm{x}$. Nilai koefisien korelasi adalah 0.88 dan nilai koefisien determinasi sebesar $74.90 \%$, dengan $\mathrm{x}$ adalah $\mathrm{V}_{\text {etanol(DB) }}$ dan y adalah daya berkecambah setelah benih disimpan.

\section{SARAN}

Metode pengusangan cepat dengan perendaman benih ke dalam larutan etanol $20 \%$ selama 90 menit dapat digunakan sebagai pelengkap uji mutu benih caisin. Tolok ukur yang digunakan adalah $\mathrm{V}_{\text {etanol(DB) }}$ (daya berkecambah benih setelah pengusangan dalam etanol). Nilai daya berkecambah sebesar $85 \%$ pada kondisi ruang simpan dengan suhu 23.3-29.9 ${ }^{\circ} \mathrm{C}$ dan RH 61-85\% dalam kemasan aluminium foil setelah penyimpanan 3 dan 6 bulan dapat diperoleh pada nilai $\mathrm{V}_{\text {etanol(DB) }}$ masing-masing minimum $\geq(58.63 \pm 3.72) \%$ dan $\geq(80.44 \pm 3.58) \%$. Penyempurnaan model pendugaan vigor daya simpan dapat dilakukan dengan menggunakan jumlah sampel yang lebih banyak. Percobaan dapat dilakukan pada komoditas lain sehingga pengujian daya berkecambah dan penetapan masa edar benih dapat diberikan tanpa tergantung pada umur maupun kondisi simpan benih sebelumnya.

\section{DAFTAR PUSTAKA}

Addai, L.K., O.S. Kantanka. 2006. Evaluation of screening methods for improved storability of soybean seed international. J. Botany. 2(2): 152-155.

Budiman, D.F. 2012. Uji pengusangan cepat terkontrol (PCT) untuk menduga viabilitas benih cabai merah (Capsicum annum L.) setelah penyimpanan [Skripsi]. Institut Pertanian Bogor. Bogor.

[Dirbenhorti] Direktorat Perbenihan Hortikultura. 2013. Pedoman Teknis Sertifikasi Benih Tanaman Hortikultura. Direktorat Jenderal Hortikultura, Kementerian Pertanian. Jakarta.

Ekowahyuni, L.P., S.H. Sutjahjo, S. Sujiprihati, M.R. Suhartanto, M. Syukur. 2012. Metode pengusangan cepat untuk pengujian vigor daya simpan benih cabai (Capsicum annuum L.). J. Agron. Indonesia. 40(2): 132-138.

Jyoti, C.P. Malik. 2013. Seed deterioration: a review. Int. J. LifeSc. Bt \& Pharm. Res. 2(3): 374-385.

Priestley, D.A., AC. Leopold. 1980. Alcohol stress on soya bean seeds. Ann. Bot. 45(1): 39-45. 
Qadir, A. 2012. Pemodelan pertumbuhan tanaman kedelai (Glycine $\max \mathrm{L}$. Merrill) di bawah cekaman naungan. [Disertasi]. Institut Pertanian Bogor. Bogor.

Rosida, A., M. Sari, A. Qadir. 2015. Pendugaan vigor daya simpan benih kubis (Brassica oleracea L. var. capitata) menggunakan metode pengusangan cepat dengan etanol. J. Hort. Indonesia. 6(3): 152-160.

Sadjad, S., E. Murniati, S. Ilyas. 1999. Parameter Pengujian Vigor Benih dari Komparatif ke Simulatif. Grasindo Persada. Jakarta.
Salehi, M.R., F. Ashiri, H. Salehi. 2008. Effect of different ethanol concentrations on seed germination of three turfgrass genera. Nat. Appl. Sci. 2(1): 6-9.

Shaban, M. 2013a. Review on physiological aspects of seed deterioration. Intl. J. Agri. Crop. Sci. 6(11): 627-631.

Shaban, M. 2013b. Aging in orthodox seeds is a problem. Intl J. Advanced Biol. Biomed. Res. 1(11): 1296-1301.

Woodstock, L.W., R.B. Taylorson. 1981. Ethanol and acetaldehyde in imbibing soybean seeds in relation to deterioration. Plant Physiol. 67: 424-428. 